\title{
EXAMINING CONSTITUTIONAL AWARENESS AND STRENGTHENING JUDICIAL INTEGRITY
}

\author{
Retno Mawarini Sukmariningsih \\ Faculty of Law, University of 17 Agustus 1945, Semarang, Indonesia \\ Email: mawarini_sukma@yahoo.co.id
}

\begin{abstract}
This article is aimed to review constitutional awareness and decision-strengthening practice in judicial institutions. As it turns out in practice, however, the legal decisions are still debatable in reality. The practice of abuse of authority in the judiciary tends to damage the pillars of the judiciary and result in a decline in trust and certainly the authority of the judiciary against society. It is a normative legal research (doctrinal research). The approach used is qualitative analysis and the application of legislation. The results of research indicate that the strengthening of the judge' decision can be started from the quality of decision through a comprehensive and mind-opened dimension, so that it is necessary to increase the pattern of development not only by the judges but also by all relevant stakeholders such as the Secretariat General and the Registrar Apparats. The focus of development is not only about knowledge but also it was conducted from all aspects such as mental and spiritual development that conducted continuously. The consequences of providing sufficient budget to realize it and in its implementation are conducted with full responsibility.
\end{abstract}

Keywords: Constitution, decision, legal obedience, judicial institution

\section{A. INTRODUCTION}

In Indonesia, the judicial power in state agency is the Constitutional Court and the Supreme Court. The Constitutional Court is a state agency that has a dignity to protect the constitution for enforcement the Constitution and a constitutional state and democracy in the life of a dignified nation and state (Untoro, Self Respect dan Kesadaran Hukum Pejabat Tata Usaha Negara Menuju Keadilan, (Seminar Nasional Hukum: Fakultas Hukum Universitas Negeri Semarang, 2016), p. 389406). Certainly, to realize this the spirit of all stakeholders is needed. Not only the Constitutional judges but the Registrar Apparatus and the General Secretariat of the Constitutional Court are integrated and systematic elements that must always be maintained for the sake of constitutionality and constitutional awareness culture while the Supreme Court is one of the Judicial institutions that has the function of judicial review law under a law that is contrary to higher legislation (Ida Keumala Jeumpa, 2016: 147-176).

The judiciary decision both the Supreme Court and the Constitutional Court as a judicial institution should have strength in its legal decision stating for the sake

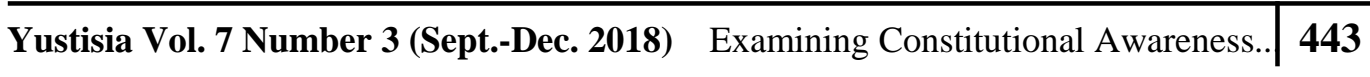

(C)2018; This is an Open Acces Research distributed under the term of the Creative Commons Attribution Licencee (https://Creativecommons.org/licences/by/4.0), which permits unrestricted use, distribution, and reproduction in any medium, provided the original works is properly cited. 
of justice based on the One God Almighty. In reality, there is still debate about the contents of legal decisions issued by the two state institutions, namely the Constitutional Court and Supreme Court. For example, the Constitutional Court' Decision Number93/PUU-XV/2017 and the Supreme Court' Decision Number47 and Number 55 $\mathrm{P} / \mathrm{HUM} / 2018$ to cancel the regulation of the General Election Commission which prohibits corruption cases prisoner become legislative candidates. There is a potential for disability formally because it is contrary to Law Number 24 of 2003 on the Constitutional Court. Two the regulation of the General Election Commission that canceled by the Supreme Court namely PKPU Number 26 of 2018 on the nomination of Regional Representative Council members, and PKPU Number 20 of 2018 on the nomination of House of Representatives and Council Regional Representative. These cancellations by PKPU is contrary to Law Number 7 of 2017 on General Elections.

In the election law allows corruption ex-prisoners to nominate himself for legislative membership, while the General Election Commission prohibits it. The question, is there a mistaken logic in interpreting the law? so that the regulation of the General Election Commission issued regarding the prohibition of corruption exprisoners from nominating as legislative members? While, the election law is also not spared from the petition for judicial review, there are even 4 (four) substances that were filed for judicial review in the Constitutional Court, namely the presidential threshold for the nomination, the tenure of the vice-president, campaign funds and understanding of self-image in the campaign while in Article 55 of Law Number 24 of 2003 regarding the Constitutional Court stated that the review of laws and regulations under the law being carried out by the Supreme Court must be stopped if the law which is the basis for reviewing the regulation is in the process of being reviewed by the Constitutional Court until a decision is made by the Constitutional Court. The decision of the Constitutional Court Number 93/PUU-XV/2017 states that the moratorium for judicial review in the Supreme Court is carried out if the law that becomes reviewing material being tested by the Constitutional Court.

Furthermore, the cancellation of the two regulation of the General Election Commission concerning the prohibition of corruption ex-prisoner become legislative candidate by the Supreme Court was conducted precisely when the legislative members has problems. The phenomenon that occurred showed that there were approximately 144 members of the House of Representative and Council Regional Representatives who are still in the legal process (2004-2017), certainly it does not include 41 members of the Council Regional Representatives in Malang and 38 members of the Council Regional Representatives in North Sumatra in which this year are in legal process. This is very ironic when Indonesia is being incessantly to fight crimes including extraordinary crimes with consideration of contradicting the law. Materially it is contrary to the law but is there no mistaken logic when this is

444 Yustisia Vol. 7 Number 3 (Sept.-Dec. 2018) $\quad$ Examining Constitutional Awareness... 
contrary to the principle of propriety? This is a necessary comprehensive dimension including the mind-opened in perform their duties as a judge which ultimately as a form of decision-strengthening the judge.

\section{B. PROBLEM STATEMENT}

According to the problems described in the introduction, this article aimed to review how is constitutional awareness and decision-strengthening practice in judicial institutions?

\section{RESEARCH METHODS}

The research is a normative legal research (doctrinal research). It used a qualitative analysis and legislation approaches. Thus, the choice of relevant material and integrated interpretation during interviews with stakeholders related to the main research issues.

\section{DISCUSSION AND RESEARCH RESULTS}

In the practice of abuse of authority in the judicial body, it tends to damage the pillars of the judiciary and result in a decline in trust and certainly the authority of the judiciary towards the community. Thus, such conditions cannot be allowed continuously, it needs an effort that is oriented towards the creation of a judicial body and judges who with righteousness can guarantee the community as a justice seeker.

The future of judicial institutions in Indonesia is required to always be more productive, efficient and operational and not allergic to accepting changes because a change is needed by agent of change. The way of life of agents of change is the way of life of the heroes. Change agents are not always smooth in their journey, even there are many challenges because they require struggle and never believe in promises that can offer success quickly without struggle. Likewise, promises that justify all means. The challenge faced by an agent of change must not be discouraged (Raharjo Satjipto, 1990: 28-29). Many examples that we can learn from these valuable lessons such as when Colonel Sanders (Kentucky Fried Chicken) failed to offer the idea of selling fried chicken with a recipe in particular as many as 1.009 times. Then, Thomas Alfa Edison failed more than 10.000 times before finding filament lights.

Furthermore, the cancellation of two regulation of the General Election Commission concerning the prohibition of corruption cases ex-prisoner become legislative candidate by the Supreme Court was conducted precisely when the legislative members tripped over the legal process. The phenomenon that occurred showed that there were approximately 144 members of the House of Representative and Council Regional Representatives who are still in the legal process (2004-2017),

Yustisia Vol. 7 Number 3 (Sept.-Dec. 2018) $\quad$ Examining Constitutional Awareness.. 445 
certainly it does not include 41 members of the Council Regional Representatives in Malang and 38 members of the Council Regional Representatives in North Sumatra in which this year are in legal process (Kompas, Saturday 15 September 2018). This is very ironic when Indonesia is being incessantly to fight crimes including extraordinary crimes with consideration of contradicting the law. Materially it is contrary to the law but is there no mistaken logic when this is contrary to the principle of propriety? This is a necessary comprehensive dimension including the mindopened in perform their duties as a judge which ultimately as a form of decisionstrengthening the judge. Because it has become a legal decision (the Supreme Court), it is the duty of anyone to respect them and must be carried out.

Furthermore, the wise people said that success is not a person who never fails, they are just people who never give up, because in fact the biggest failure in life is if we do not want to learn from that failure. The agents of change needed by the Constitutional Court at this time are those who carry out their work are able to produce results and processes and are able to achieve the targets set by the agent of change and are not afraid to create and innovate in order to protect the Constitutional Court as a guardian of the Constitution. Reisman also asserted that the main function of the law is to determine the sources of ways of making law, both materially and symbolically meaning that the law can be applied to society as well as to determine procedures for law-making (Menachem Mautner and Michael Reismans, 2009: 505-506).

Paying attention to the Ethics Council, it was established to maintain the dignity of the Constitutional Court' decision to conform to the community' expectations in their functions as guardians of the constitution (Muhammad Anwar Tanjung, and Retno Saraswati, 2018: 379-399). For this reason, the existence of the Ethics Council, as established through the regulation of the Constitutional Court Number 2 of 2014, is important to guard the Constitutional judges.

The main requirements for being a member of the Ethics Council are over 60 years old and come from 3 (three) components, namely former Constitutional Judge, community leaders, and professors or senior academics. The duty of the Ethics Council is to maintain the dignity of the Constitutional Judge as a partner in dialogue for the good and to maintain the legitimacy of the Constitutional Judge. Basically, the Constitutional Court is 9 Constitutional Judges themselves and not as gods.

In its duties, judicial officers, especially judges are bound by procedural law rules, material law and code of ethics or code of conduct for judges. The case of Akil Muchtar and Patrialis Akbar is certainly a valuable lesson for the judicial apparatus and for all of us. The arrest of former Chief of the Constitutional Court Akil Mochtar in 2013 should have been the first and last, but precisely in 2017 Patrialis Akbar who was arrested by the Corruption Commission Eradication officers, added a long line that injured the judiciary that had the duty to guard or maintain this constitution.

446 Yustisia Vol. 7 Number 3 (Sept.-Dec. 2018) $\quad$ Examining Constitutional Awareness... 
There were changes that occurred but not negative changes to positive but changes that occur from negative to more negative. This must be evaluated.

As pattern of development is not only by the judges but it was conducted for all related stakeholder such as the elements of Secretariat General Registrar. The focus of development is not only the knowledge but it is also conducted through the development for all aspects includes mental and spritual developments that conducted continuously. Certainly, it will add consequence for delivering enough budget for the implementation of development as it conducted in intensive and full responsible. In addition, the patters of development are also strengthened the positioning of the Council of Ethics the Constitutional Court by develop positive reputation and public trust, out from a bad image (two big cases that involves two the Constitutional Court), it is sufficient as examples of bad image for the Constitutional Court as a State institution to maintain the constitution. And able to act as a role model of justice reform such as (implementing JR for regulations under the Act implemented in the Supreme Court) and having high performance and competitive advantage sources.

During this, the Constitutional Court has showed its professionalism in its duties and authorities, but it is not enough if it is not accompanied by integrity to maintain the independence of the Constitutional Court as a judicial institution. Integrity related to the appreciation of the values of the judicial profession as an instrument to maintain the quality of the judge' decision (Atang Hermawan Usman, 2015: 26-53). According to the American Legal Realism and Pragmatic Legal Realism and Secandinavia that the judge decision that has permanent legal power is actually the law, which is the problem that the judge decision much influenced by various factors, both internal and external factors. So it does not rule out the possibility that the judge decision is in favor of certain interests and ignores the sense of justice. According to Lon Fuller in the formation of a fair law in his book The Morality of Law, indicated that the laws must be made in such a way that they can be understood by ordinary people. Some of the initiatives by the Constitutional Court included the implementation and strengthening of a culture of integrity and a corruption-free zone in the constitutional court.

In strengthening the decisions of both the Constitutional Court and the Supreme Court, the quality of the judge decision must be taken into account, which must take into account the comprehensive dimensions including the mind-opened and the correctness of the mind in its duties as a judge and always guided by an objective view. Friedrich Carl Von Sovigny in his famous book "Von Beruf Unserer Zeit Fur Gesetzgebung und Rechtswissenschaft," "About the Duties of Our Times For Law and Legal Formers," among others said: "Das Recht wird nicht gemacht, est ist und wird mit dem Volke" (the law was not made, but grew and developed with the community) (Lili Rasjidi and Ira Rasjidi, 2001: 65). Von Savigny' view that in this

Yustisia Vol. 7 Number 3 (Sept.-Dec. 2018) Examining Constitutional Awareness... 
world there are various kinds of nations which in each nation have a Volkgeist or soul of the people. Sosietas ibi, ibi ius. where there is a community, there is a law.

Furthermore, in improving the constitutional awareness, a procedural is needed that can be used as a way for interactive dialogue held by the Constitutional Court in collaboration with broadcasting media (TV/Radio) which has the purpose of disseminating various issues concerning the authority of the Constitutional Court and the Constitution to the general public with the headline which is not too formal but the educational aspect can be understood by ordinary people, because the target is not middle to upper class society but middle to lower. The Constitutional Court can cooperate with the Teaching Association of the Procedural Law of the Constitutional Court or the Teaching Association of HTN/HAN to have a Target Village in realizing the existence of a constitutionally aware village. Constitutional dialogue is packaged with a mild problem first to introduce the institution and then the constitution. The first target is the people who live in rural areas in collaboration with Public Broadcasting Institution (Retno Mawarini Sukmariningsih, Focus Group Discussion Rencana Strategis (RENSTRA) Mahkamah Konstitusi Tahun 2015-2019 at Hotel Patra Jasa, Semarang, 1 December 2017).

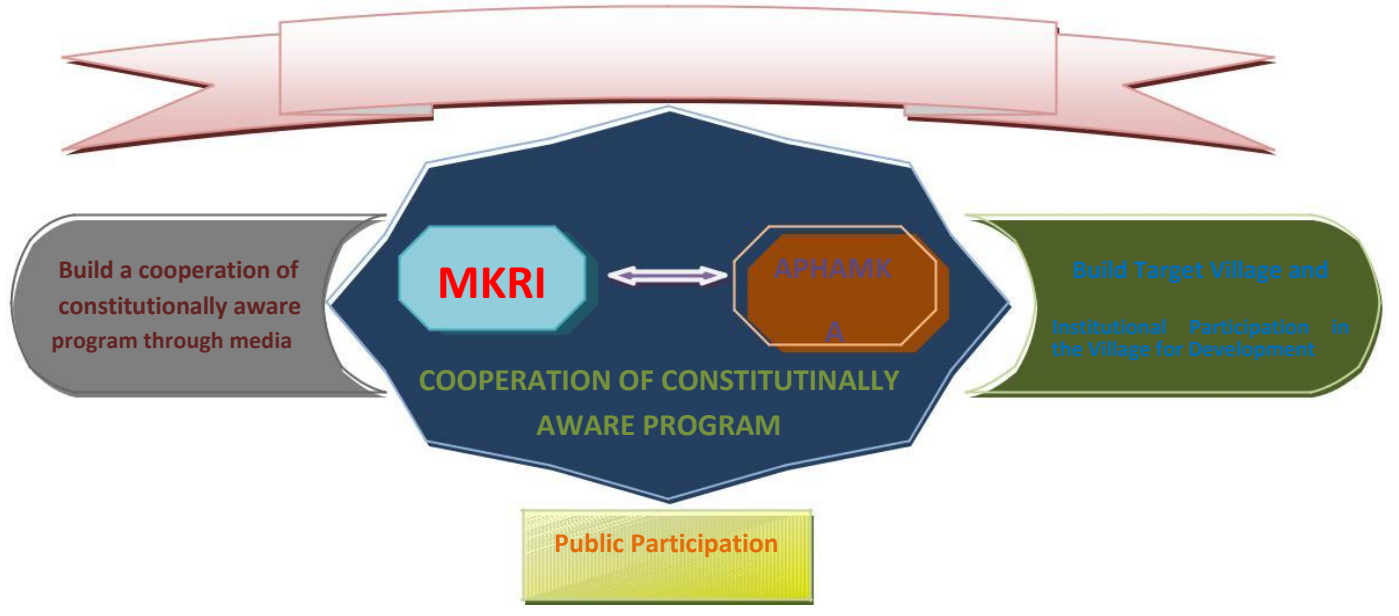

Figure 1. Ideal pattern of the Constitutionally Aware Program through various forms of activities

During this, there is a problem that has been a fact that requires handling such as:

1. Community understanding of the 1945 Constitution of the Republic of Indonesia and the Constitutional Court of the Republic of Indonesia is not evenly distributed.

2. Lack of ordinary people understanding of their constitutional rights.

3. Institutional reach of the Constitutional Court of the Republic of Indonesia

448 Yustisia Vol. 7 Number 3 (Sept.-Dec. 2018) $\quad$ Examining Constitutional Awareness... 
Although the constitution guarantees every citizen for freedom to express opinions, gather, but the commitment is needed to remain in the corridor of the constitution, namely the 1945 Constitution of the Republic of Indonesia, and Pancasila, so that it requires collaboration with study centers on campuses and as an activity that can be easily accessed by the public, it is necessary to collaborate with the Public Broadcasting Institution as a partner in disseminating the constitution with the packaging of the Constitutional Meeting with the principles of Informative, Educative and Participatory.

As in the figure below:

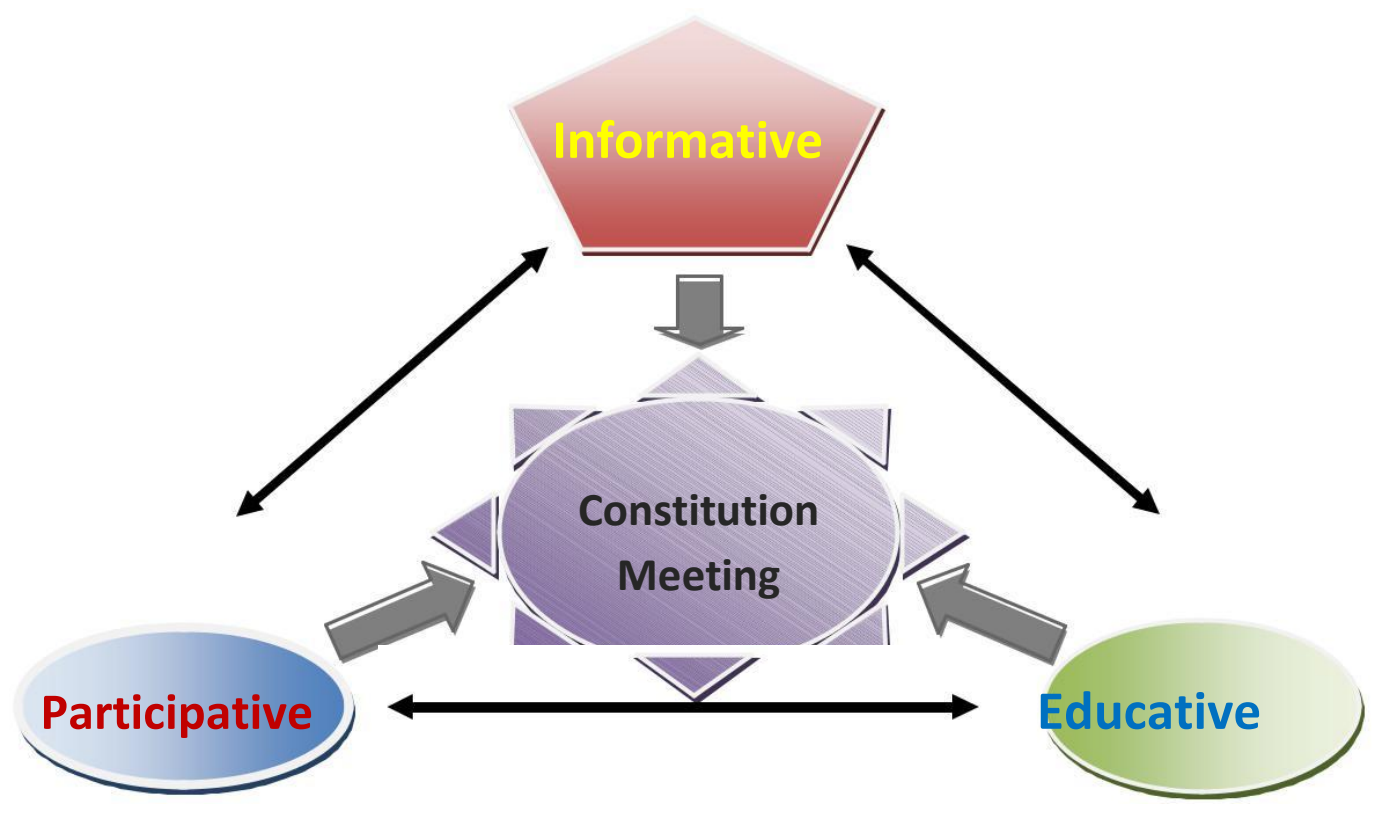

Figure 2. Pattern of activity principle

\section{E. CONCLUSION}

The strengthening the judge decision can be started from the quality of the decision through a comprehensive and mind-opened dimension, so that it is necessary to increase the pattern of development is not only by the judges but also by all relevant stakeholders such as the Secretariat General and the Registrar Apparatus. Above all, the focus of developing is not only about knowledge but also it is also conducted from all aspects such as mental and spiritual development that conducted continuously. The consequences of providing sufficient budget to realize it and in its implementation are conducted with full responsibility. Hence, program creativity is expected to encourage the acceleration of the constitutionally aware program in

Yustisia Vol. 7 Number 3 (Sept.-Dec. 2018) Examining Constitutional Awareness... 
collaboration with the Study Centers of Constitutional Studies to have a target village. The program is not too formal packed with the Constitutional Aware Meeting by still adhering to the principle of activities that are informative, educative and participatory.

\section{BIBLIOGRAPHY:}

\section{Books:}

Nonet, Philippe dan Philip Selznick, 1978, Law and Society in Transition: Toward Responsive Law, Harper and Row Publisher: London.

Raharjo, Satjipto, 1990, Hukum dan Masyarakat (Law and Society), Angkasa: Jakarta.

Rasjidi, Lili \& Ira Rasjidi, 2001, Dasar Dasar Filsafat dan Teori Hukum (The Basics of The Philosophy and Legal Theory), Citra Adidya Bakti: Bandung.

Sukmariningsih, Retno Mawarini, Presented on the event of Focus Group Discussion Rencana Strategis (RENSTRA) Mahkamah Konstitusi Tahun 2015-2019 at Hotel Patra Jasa, Semarang, 1 December 2017.

\section{Journals:}

Atang Hermawan Usman, 2015, Kesadaran Hukum masyarakat dan Pemerintah sebagai Faktor Tegaknya Negara Hukum di Indonesia. Jurnal Wawasan Yuridika, 30(1), 26-53.

Ida Keumala Jeumpa. (2014). Contempt of Court: Suatu Perbandingan antara Berbagai Sistem Hukum. Kanun: Jurnal Ilmu Hukum, 16(1), 147-176.

Menachem Mautner and Michael Reismans, (2009) Jurisprudence of Suspicion.” The Yale Journal of International Law, Vol. 34: 505-506

Muhammad Anwar Tanjung, and Retno Saraswati, (2018), "Demokrasi dan Legalitas Mantan Narapidana dalam Pemilihan Kepala Daerah dan Pemilihan Umum", Jurnal Hukum IUS QUIA IUSTUM, 25 (2): 379-399,

Untoro. (2016). Self Respect dan Kesadaran Hukum Pejabat Tata Usaha Negara Menuju Keadilan. (Seminar Nasional Hukum: Fakultas Hukum Universitas Negeri Semarang): Volume 2 Nomor 1 Tahun 2016, 389-406.

\section{Newspaper:}

Kompas, Saturday 15 September 2018

\begin{tabular}{l|ll}
\hline 450 & Yustisia Vol. 7 Number 3 (Sept.-Dec. 2018) & Examining Constitutional Awareness...
\end{tabular} 